\title{
TINGKAT KESUKAAN CHOUX PASTRY KERING DENGAN SUBSTITUSI TEPUNG IKAN GABUS
}

\author{
Esthy Rahman Asih', Yuliana Arsil ${ }^{1}$ \\ Jurusan Gizi Poltekkes Kemenkes Riau ${ }^{1}$ \\ email korespondensi: esthy@pkr.ac.id
}

\begin{abstract}
One of the local food ingredients that can be used as a source of protein is cork fish. Cork fish can be processed into flour, which can reduce damage and increase added value. This fish meal can be prepared into various snacks, one of which is a crispy choux pastry. Higher protein content with the substitution of cork fish flour in this crispy choux pastry has the potential to be a high-protein snack. This study aims to determine the sensory evaluation of crispy choux pastry formulation with cork fish meal substitution. The experimental design used in this study was CRD (Complete Randomized Design). The formulation of cork fish meal substitution in the production of crispy choux pastry is 0,15 , 30 and $45 \%$. The resulted choux pastry was tested on the sensory evaluation at 30-semitrained panellists. The results showed that the substitution of cork fish flour had a significant effect on the color, aroma and texture preference parameters. The substitution of cork fish flour in making crispy choux pastry by $15 \%$ is the best treatment with a color preference level value (5.80); taste (5,33); aroma (5,27); and texture (6.53).
\end{abstract}

\section{Keywords: crispy choux pastry, cork fish, sensory evaluation}

\begin{abstract}
Abstrak
Salah satu bahan pangan lokal yang dapat dijadikan sumber protein adalah ikan gabus. Ikan gabus dapat diolah menjadi tepung yang sehingga dapat mengurangi kerusakan dan meningkatkan nilai tambah. Tepung ikan ini dapat diolah menjadi berbagai makanan selingan salah satunya adalah choux pastry kering. Kandungan protein yang lebih tinggi dengan substitusi tepung ikan gabus pada choux pastry kering ini berpotensi sebagai makanan selingan tinggi protein. Tujuan penelitian ini adalah untuk mengetahui tingkat kesukaan formulasi choux pastry kering dengan substitusi tepung ikan gabus. Rancangan percobaan yang digunakan dalam penelitian ini adalah RAL (Rancangan Acak Lengkap). Formulasi substitusi tepung ikan gabus dalam pembuatan choux pastry kering adalah $0,15,30$ dan $45 \%$. Choux pastry yang dihasilkan akan dilakukan uji tingkat kesukaan terhadap 30 panelis semi terlatih. Hasil penelitian menunjukkan bahwa substitusi tepung ikan gabus berpengaruh nyata terhadap parameter tingkat kesukaan warna, aroma dan tekstur. Substitusi tepung ikan gabus dalam pembuatan choux pastry kering sebesar $15 \%$ merupakan perlakuan terbaik dengan nilai tingkat kesukaan warna $(5,80)$; rasa $(5,33)$; aroma $(5,27)$; tekstur $(6,53)$.
\end{abstract}

\section{Kata kunci : choux pastry kering, ikan gabus, tingkat kesukaan}

Program diversifikasi pangan untuk memperbaiki gizi masyarakat dapat berkembang dengan baik apabila memanfaatkan potensi bahan pangan lokal yang ada. Ikan gabus (Channa striata) merupakan salah satu ikan perairan umum yang pemanfaatan cukup besar. Ikan gabus mengandung protein sebesar 79,9\% (bb) (Sari, Marliyati, Kustiyah, Khomsan, \& Gantohe, 2014). Rata-rata kadar protein terlarut tepung ikan gabus berkisar antara 2,34\% dan 10,88\% (Fatmawati dan Mardiana, 2014). Ikan ikan gabus mengandung 15 jenis asam amino dengan tiga 
asam amino esensial pada konsentrasi tertinggi yaitu lisin sebesar 1,67\%, arginin sebesar 1,34\%, dan leusin sebesar 1,13\% (Sari dkk., 2014). Penelitian (Kusumawardhani, Mexitalia, \& Kosnadi, 2006) terjadi kenaikan bermakna kadar serum albumin pada kelompok perlakuan disebabkan digestibilitas yang baik dan lebih tingginya kandungan asam amino esensial pada ikan gabus.

Selama ini, pemanfaatan ikan gabus masih terbatas umumnya sebagai ikan konsumsi sehingga perlu upaya diversifikasi hasil olahan perikanan. Diversifikasi hasil olahan perikanan bertujuan untuk meningkatkan nilai tambah (added value) dari ikan segar dan juga mengatasi sifat ikan yang mudah busuk (perishable). Pengolahan tepung ikan merupakan salah satu bentuk diversifikasi hasil olahan setengah jadi (intermediate). Tepung ikan gabus mengandung protein cukup tinggi sehingga dapat dijadikan sumber protein pada produk olahan pangan yang lain. Penelitian tentang substitusi tepung ikan gabus dalam pembuatan biskuit telah dilakukan. Konsentrasi tepung ikan pada pembuatan biskuit fungsional memberikan perbedaan nyata terhadap tekstur biskuit. Biskuit berbasis tepung ikan dapat digunakan sebagai makanan selingan (snack) karena kandungan zat gizi pada produk tersebut lebih baik kualitasnya, dibandingkan cookies pada umumnya yang cenderung tinggi karbohidrat dan lemak serta kurang seimbang kandungan gizi lainnya (Sari et al., 2014).

Choux pastry kering merupakan salah satu jenis dari produk choux paste yang sudah dikenal di Indonesia. Makanan ringan berwarna kecokelatan ini berukuran kecil dengan tekstur renyah, berongga dan berasa gurih serta menyerupai sayuran bunga kol (Betari \& Pangesthi, 2016). Penelitian ini bertujuan untuk menentukan formulasi choux pastry dengan substitusi tepung ikan gabus yang disukai oleh panelis.

\section{METODE}

\section{Alat dan Bahan}

Alat yang digunakan dalam penelitian ini adalah panci presto, oven listrik, blender kering, mixer, kertas saring, timbangan analitik, spektrofotometri serapan atom dan alat-alat gelas untuk analisis kimia. Bahan yang digunakan dalam penelitian ini adalah ikan gabus segar, bahan baku pembuatan choux pastry kering yaitu tepung terigu, margarin, telur, garam dan air yang diperoleh dari pasar lokal. Bahan kimia yang digunakan adalah $\mathrm{H}_{2} \mathrm{SO}_{4}$ pekat, $\mathrm{NaOH}$, indikator $\mathrm{PP}$, asam borat $2 \%, \mathrm{HCl} 0,01 \mathrm{~N}$, pelarut heksan, larutan standar $\mathrm{Ca}$.

\section{Tahapan Penelitian}

Prosedur pembuatan tepung ikan gabus (Sari et al., 2014) dimulai dari tahap pembersihan ikan dan penghilangan kepala, ekor, isi perut, sisik, serta sirip. Selanjutnya ikan dibelah dibagian punggung dan dilakukan pencucian menggunakan air bersih sebanyak 3 kali ulangan. Modifikasi dalam penelitian ini adalah ikan dimasak menggunakan panci presto selama 90 menit, sampai daging dan tulang ikan menjadi lembut dan hancur. Setelah selesai pemasakan dengan panci presto, pisahkan tulang dan daging ikan dari kulit yang ada. Kulit ikan dalam penelitian ini tidak digunakan karena akan membuat tepung ikan yang dihasilkan semakin berwarna coklat. Daging ikan dan tulang yang diperoleh dikeringkan menggunakan oven pada suhu $50^{\circ} \mathrm{C}$ sampai kadar air kurang dari $10 \%$. Selanjutnya daging ikan yang telah kering dihaluskan menggunakan blender kering dan dilakukan pengayakan agar diperoleh butiran tepung ikan yang dengan 
ukuran 60 mesh. Tepung ikan gabus dianalisis kadar air dengan metode oven (SNI, 1992), kadar protein (SNI, 1992), kadar abu dengan metode pemijaran (SNI, 1992), kadar lemak (SNI, 1992), kadar karbohidrat (by difference) dan kadar kalsium dengan Atomic Absorption Spectrofotometer (AAS) panjang gelombang $420 \mathrm{~nm}$ (AOAC, 2005).

Penelitian utama dilakukan dengan mensubstitusikan tepung ikan gabus dalam pembuatan choux pastry kering. Prosedur pengolahan choux pastry kering diawali dengan mencampurkan margarin, air dan garam sampai mendidih dengan perebusan. Mencampurkan tepung terigu dan tepung ikan gabus sesuai formulasi sambil dimasak dengan api kecil sampai kalis. Memasukkan telur ke dalam adonan suam-suam kuku (suhu $50^{\circ} \mathrm{C}-60^{\circ} \mathrm{C}$ ) kemudian dimixer dengan kecepatan sedang selama 2 menit. Pencetakan adonan dilakukan dengan memasukkan adonan dalam piping bag yang ujungnya diberi spuit bintang. Adonan disemprotkan dalam loyang yang telah diolesi margarin. Pemanggangan dilakukan sebanyak 2 kali. Pemanggangan pertama pada suhu $200^{\circ} \mathrm{C}$ selama 15 menit dan pemanggangan kedua pada suhu $130^{\circ} \mathrm{C}$ selama 15 menit. Sebelum dikemas, choux pastry kering didinginkan terlebih dahulu untuk menghilangkan uap panas.

Choux pastry kering selanjutnya diuji tingkat kesukaan terhadap warna, rasa, aroma dan tekstur pada 30 panelis semi terlatih. Uji hedonik dengan menggunakan panelis semi terlatih sebanyak 30 panelis dari mahasiswi Jurusan Gizi Poltekkes Kemenkes Riau dengan kriteria penilaian 1: sangat tidak suka, 2: tidak suka, 3: agak tidak suka, 4: netral, 5: agak suka, 6: suka, 7: sangat suka.

\section{Formulasi Bahan}

Formulasi pembuatan choux pastry kering didasarkan pada 4 taraf perlakuan yaitu $0 \%, 15 \%, 30 \%$ dan $45 \%$ tepung ikan dari total tepung yang digunakan dalam adonan. Formulasi bahan dalam pembuatan choux pastry kering dapat dilihat pada Tabel 1.

Tabel 1. Formulasi Bahan Pada Setiap Perlakuan

\begin{tabular}{|l|c|c|c|c|}
\hline \multicolumn{1}{|c|}{ Bahan } & $\begin{array}{c}\text { A } \\
\text { (gram) }\end{array}$ & $\begin{array}{c}\text { B } \\
\text { (gram) }\end{array}$ & $\begin{array}{c}\text { C } \\
\text { (gram) }\end{array}$ & $\begin{array}{c}\text { D } \\
\text { (gram) }\end{array}$ \\
\hline Tepung Terigu & 162,5 & 138,125 & 113,75 & 89,375 \\
\hline $\begin{array}{l}\text { Tepung lkan } \\
\text { Gabus }\end{array}$ & 0 & 24,375 & 48,75 & 73,125 \\
\hline Margarin & 125 & 125 & 125 & 125 \\
\hline Telur & 230 & 230 & 230 & 230 \\
\hline Garam & 2 & 2 & 2 & 2 \\
\hline Air & 242 & 242 & 242 & 242 \\
\hline
\end{tabular}

Keterangan : $\mathrm{A}=$ tepung ikan $0 \%$ dan tepung terigu $100 \%$

$\mathrm{B}=$ tepung ikan $15 \%$ dan tepung terigu $85 \%$

$\mathrm{C}=$ tepung ikan $30 \%$ dan tepung terigu $70 \%$

\section{Rancangan Percobaan}

$\mathrm{D}=$ tepung ikan $45 \%$ dan tepung terigu $55 \%$

Penelitian ini merupakan penelitian eksperimental dengan desain rancangan acak lengkap (RAL) yaitu substitusi tepung ikan gabus dalam pembuatan choux pastry kering. Analisis data menggunakan program komputer SPSS 17 for windows. Hasil uji hedonik dianalisis dengan menggunakan uji statistik one way ANOVA dengan derajat kepercayaan 95\%. Apabila ada 
perbedaan nyata dilakukan pengujian lanjutan dengan metode DMRT pada taraf $\alpha 5 \%$.

\section{HASIL}

Hasil penelitian ini menghasilkan tepung ikan gabus dengan warna putih kecoklatan. Rendemen tepung ikan gabus dengan cara dipresto sebesar 20,06\%. Kadar air tepung ikan gabus dalam penelitian ini sebesar $5,93 \%$. Kadar protein tepung ikan gabus adalah 65,26\%, kadar abu sebesar 18,28\%, kadar lemak sebesar $7,51 \%$, kadar karbohidrat sebesar 3,03\% dan kadar kalsium sebesar $31,00 \mathrm{mg} / \mathrm{gram}$.

Tingkat kesukaan panelis terhadap warna choux pastry kering kontrol (tanpa substitusi tepung ikan gabus) dan dengan substitusi tepung ikan gabus menghasilkan nilai 5,23 sampai dengan 6,27. Substitusi tepung ikan gabus sampai $30 \%$ menghasilkan nilai tingkat kesukaan terhadap warna yang tidak berbeda nyata dengan kontrol. Substitusi tepung ikan gabus $45 \%$ mengakibatkan terjadinya penurunan tingkat kesukaan warna pada choux pastry kering. Hasil uji hedonik terhadap warna choux pastry kering dapat dilihat pada Gambar 1.

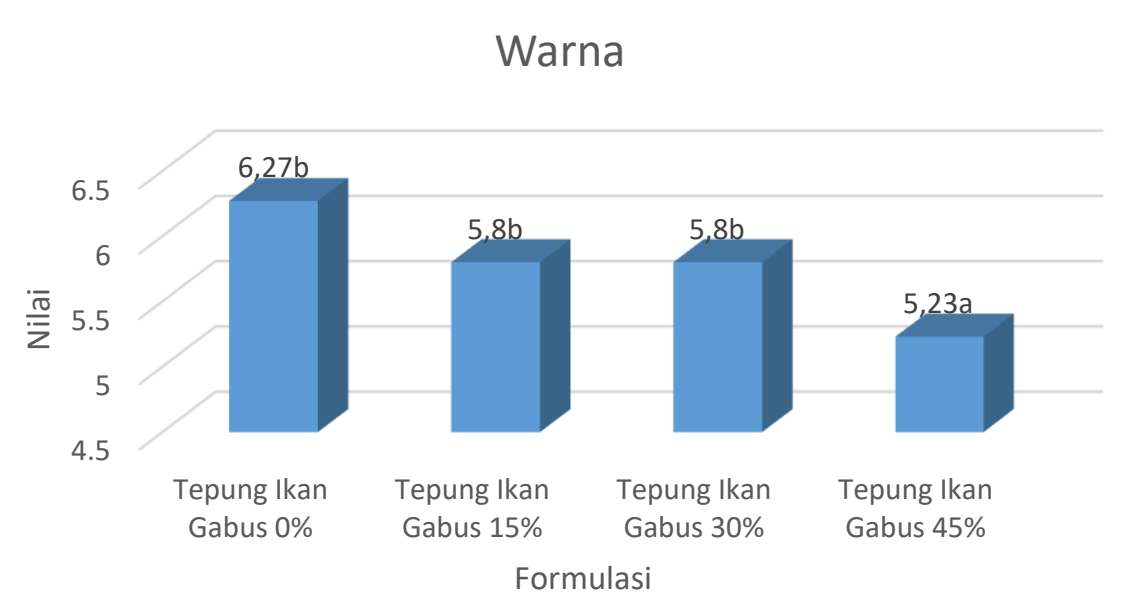

Keterangan : Angka yang diikuti dengan huruf berbeda (a,b,c,d) menunjukkan ada beda nyata dengan uji DMRT taraf signifikan $5 \%$

Gambar 1. Hasil uji hedonik terhadap warna choux pastry kering

Substitusi tepung ikan gabus sampai dengan $45 \%$ menghasilkan tingkat kesukaan terhadap rasa yang tidak berbeda nyata dibandingkan dengan kontrol (tanpa substitusi tepung ikan gabus). Hasil uji hedonik terhadap rasa choux pastry kering dapat dilihat pada Gambar 2. 


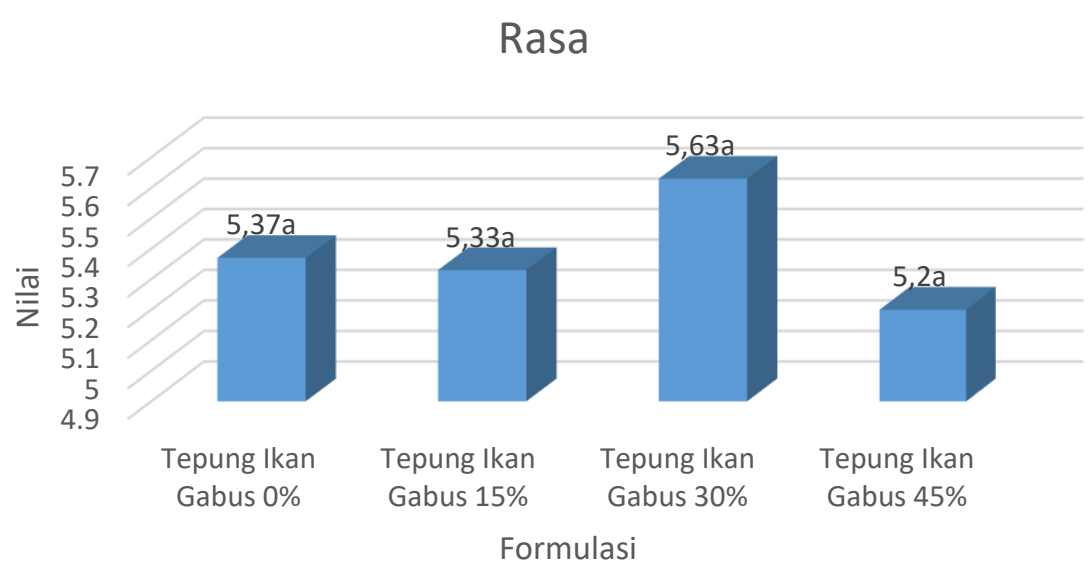

Keterangan : Angka yang diikuti dengan huruf berbeda (a,b,c,d) menunjukkan ada beda nyata dengan uji DMRT taraf signifikan $5 \%$

Gambar 2. Hasil uji hedonik terhadap rasa choux pastry kering

Tingkat kesukaan panelis terhadap aroma choux pastry kering kontrol (tanpa substitusi tepung ikan gabus) dan dengan substitusi tepung ikan gabus menghasilkan nilai 4,43 sampai dengan 5,6. Substitusi tepung ikan gabus sampai $30 \%$ menghasilkan nilai tingkat kesukaan terhadap aroma yang tidak berbeda nyata dengan kontrol. Substitusi tepung ikan gabus 45\% mengakibatkan terjadinya penurunan tingkat kesukaan aroma pada choux pastry kering. Hasil uji hedonik terhadap aroma choux pastry kering dapat dilihat pada Gambar 3.

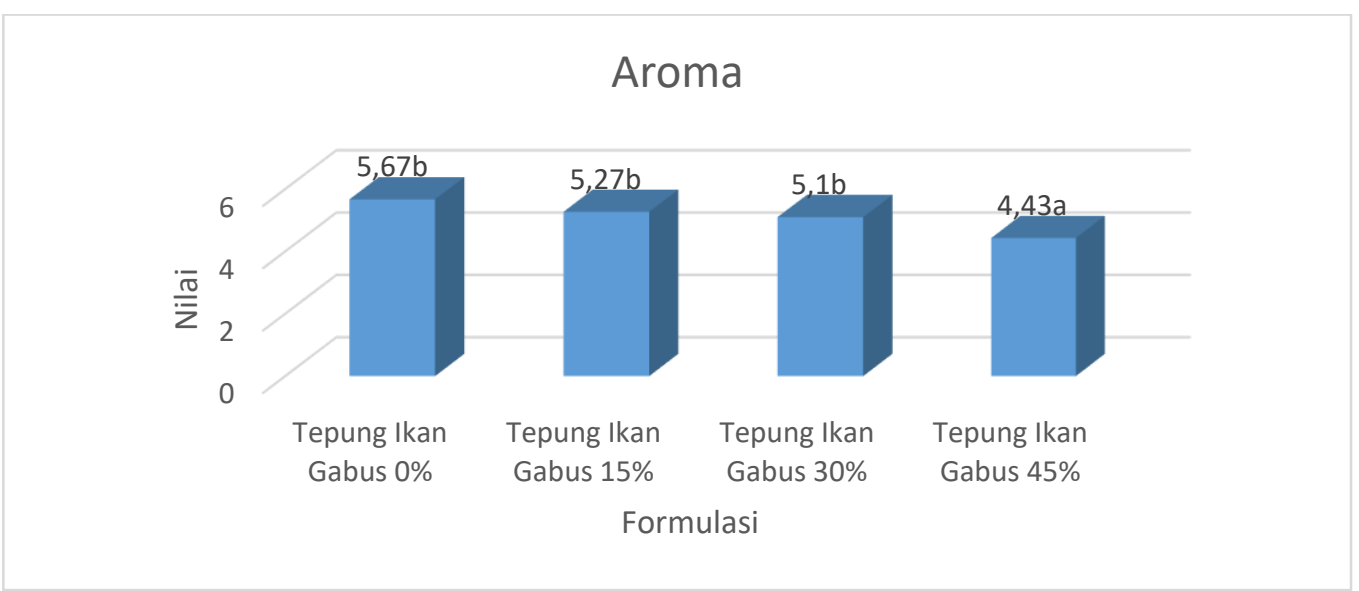

Keterangan : Angka yang diikuti dengan huruf berbeda (a,b,c,d) menunjukkan ada beda nyata dengan uji DMRT taraf signifikan $5 \%$

Gambar 3. Hasil uji hedonik terhadap aroma choux pastry kering Tingkat kesukaan panelis terhadap tekstur choux pastry kering kontrol dan dengan substitusi tepung ikan gabus menghasilkan nilai 5 sampai dengan 6,53. Substitusi tepung ikan gabus sebesar $15 \%$ dan 30\% menghasilkan tingkat kesukaan yang berbeda nyata. Semakin banyak substitusi tepung ikan gabus menghasilkan nilai 
tingkat kesukaan terhadap tekstur yang semajin menurun. Hasil uji hedonik terhadap tekstur choux pastry kering dapat dilihat pada Gambar 4.

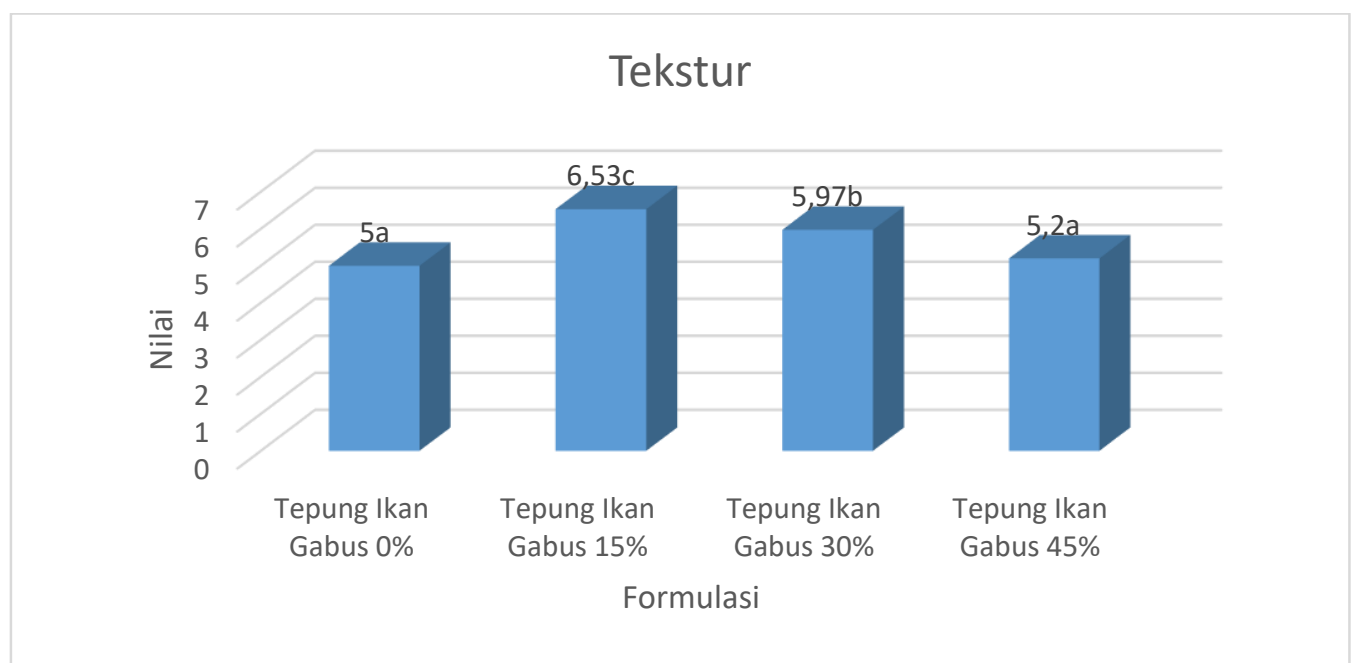

Keterangan : Angka yang diikuti dengan huruf berbeda (a,b,c,d) menunjukkan ada beda nyata dengan uji DMRT taraf signifikan $5 \%$

Gambar 4. Hasil uji hedonik terhadap tekstur choux pastry kering

\section{PEMBAHASAN}

\section{Karakteristik Tepung Ikan Gabus}

Tepung ikan merupakan produk padat yang diperoleh dengan cara mengeluarkan sebagian besar air, sebagian atau seluruh lemak dari bahan baik berupa daging ikan atau bagian ikan yang biasanya dibuang misalnya kepala ikan, isi perut dan bagian yang lain. Tepung ikan merupakan produk salah satu bentuk pemanfaatan pengolahan utama ikan maupun dari hasil tangkapan sampingan dengan komponen terbesar adalah protein. Tepung ikan merupakan salah satu sumber protein hewani yang memiliki kedudukan penting sampai saat ini dimana masih sulit digantikan kedudukannya oleh bahan baku lain apabila ditinjau dari kualitas maupun harganya. Kandungan protein tepung ikan relatif tinggi yang tersusun oleh asam amino essensial yang kompleks (Assadad, Hakim, \& Widianto, 2015).

Hasil penelitian ini menghasilkan tepung ikan gabus dengan warna putih kecoklatan. Selama proses pengeringan digunakan perlakuan pemanasan dengan oven pada suhu $50^{\circ} \mathrm{C}$ sampai kadar air maksimal $10 \%$. Perlakuan pemanasan dapat menyebabkan terjadinya reaksi browning nonenzimatis.

Rendemen merupakan berat tepung ikan yang diperoleh dibandingkan dengan berat ikan gabus segar. Hasil penelitian menunjukkan bahwa dari berat ikan 7.680 gram menghasilkan tepung ikan gabus 1.540 gram. Rendemen tepung ikan gabus dengan cara dipresto sebesar 20,06 \%. Rendemen tepung ikan gabus lebih tinggi dibandingkan dengan rendemen tepung ikan gabus pada penelitian (Fatmawati \& Mardiana, 2014) sebesar 15,58\% dan 16,47\%; rendemen tepung ikan gabus sebesar 8\% (Sari dkk., 2014). Hal ini disebabkan karena dalam 
penelitian ini digunakan pemasakan dengan presto sehingga tulang ikan yang telah lunak dijadikan juga sebagai bahan baku pembuatan tepung ikan gabus.

Kadar air tepung ikan gabus dalam penelitian ini sebesar 5,93\%. Kadar air tepung ikan gabus yang dihasilkan lebih rendah dibandingkan dengan kadar air tepung ikan gabus dengan proses pengukusan ikan selama 30 menit pada suhu $85-90^{\circ} \mathrm{C}$ sebesar $13,61 \%$ (Sari et al., 2014). Penelitian (Fatmawati \& Mardiana, 2014) menyatakan bahwa kadar air tepung ikan gabus dengan perlakuan perebusan, pengukusan dan ekstraksi lemak berkisar antara 7,46\% dan 9,18\%. Penurunan kadar air pada tepung ikan merupakan faktor penting karena kadar air berpengaruh terhadap kerusakan dan pembusukan produk (Nugroho, Dewi, \& Rianingsih, 2016). Menurut (BSN, 1996) standar kadar air tepung ikan mutu I maksimal $10 \%$.

Kadar protein tepung ikan gabus dalam penelitian ini adalah 65,26\%, kadar abu sebesar $18,28 \%$, kadar lemak sebesar $7,51 \%$, kadar karbohidrat sebesar $3,03 \%$ dan kadar kalsium sebesar $31,00 \mathrm{mg} / \mathrm{gram}$. Kadar abu pada tepung ikan dipengaruhi oleh bahan baku dan pengolahannya. Kadar lemak tepung ikan yang baik maksimal $12 \%$. Kadar lemak berpengaruh terhadap kualitas tepung ikan, jika kadar lemak tinggi akan menyebabkan tepung ikan mudah mengalami ketengikan (Handoyo \& Assadad, 2016). Pada penelitian ini kualitas kimiawi tepung ikan gabus termasuk golongan mutu I dengan kriteria kadar air maksimal 10\%, protein kasar minimal 65\%, kadar abu maksimal 20\%, kadar lemak maksimal $8 \%$ dan kadar Ca sebesar 2,5-5,0\% (SNI 01-2715- 1996).

\section{Uji Hedonik}

Choux pastry kering adalah produk pastry yang bentuknya lebih kecil dan tidak memiliki isian. Choux pastry memiliki ciri khas berongga pada bagian dalamnya dan proses pemanggangan dilakukan dua kali untuk menghasilkan produk yang kering dan renyah (Wulansari, 2016). Tingkat kesukaan panelis terhadap warna choux pastry kering kontrol dan dengan substitusi tepung ikan gabus dengan nilai 5,23 sampai dengan 6,27. Substitusi tepung ikan gabus dalam pembuatan choux pastry kering berpengaruh nyata terhadap tingkat kesukaan warna dari choux pastry kering yang dihasilkan $(p=0,001)$. Semakin banyak substitusi tepung ikan gabus menyebabkan semakin menurunnya tingkat kesukaan terhadap warna choux pastry kering. Dengan semakin meningkatnya substitusi tepung ikan gabus menyebabkan kadar protein semakin meningkat. Saat pemanggangan dengan suhu tinggi, akan terjadi reaksi antara karbohidrat (khususnya gula pereduksi) dari tepung terigu dengan gugus amin dari protein tepung ikan gabus yang akan menghasilkan warna choux pastry kering semakin coklat. Reaksi tersebut disebut dengan reaksi Maillard. Warna biskuit yang semakin coklat akan mengakibatkan penurunan tingkat kesukaan terhadap warna oleh panelis. Reaksi Maillard adalah reaksi yang terjadi antara karbohidrat khususnya gula pereduksi dengan gugus asam amina primer yang terdapat pada bahan sehingga akan menghasilkan bahan berwarna coklat yang disebut melanoidin (Arsa, 2016).

Tingkat kesukaan panelis terhadap rasa menunjukkan tidak ada beda nyata $(p=0,520)$. Nilai tingkat kesukaan terhadap rasa berkisar antara 5,20 sampai 5,63 . Semakin banyak substitusi tepung ikan gabus dalam pembuatan choux pastry kering tidak berpengaruh nyata terhadap rasa produk dibandingkan dengan choux pastry kering kontrol (tanpa substitusi tepung ikan gabus). Rasa choux 
pastry kering yang dihasilkan adalah gurih. Rasa gurih disebabkan karena penggunaan margarin, telur dan garam.

Tingkat kesukaan panelis terhadap aroma choux pastry kering berkisar antara 4,43 sampai dengan 5,67. Tingkat kesukaan panelis terhadap aroma choux pastry kering menunjukkan ada perbedaan nyata $(p=0,01)$. Substitusi tepung ikan gabus sampai $30 \%$ memberikan tingkat kesukaan terhadap aroma yang tidak berbeda nyata dengan choux pastry kontrol (tanpa substitusi tepung ikan gabus) dan substitusi dengan tepung ikan gabus sebesar 15\%. Substitusi tepung ikan gabus dalam pembuatan choux pastry kering sampai $45 \%$ menghasilkan tingkat kesukaan panelis terhadap aroma yang berbeda nyata dengan produk kontrol, substitusi $15 \%$ dan 30\%. Semakin banyak substitusi tepung ikan gabus menyebabkan tingkat kesukaan terhadap aroma choux pastry kering semakin menurun. Hal ini disebabkan karena semakin banyak tepung ikan gabus yang digunakan dalam pembuatan choux pastry kering menyebabkan aroma choux pastry berbau ikan kering, sehingga tingkat kesukaannya menurun.

Tingkat kesukaan panelis terhadap tekstur choux pastry kering kontrol dan dengan substitusi tepung ikan gabus dengan nilai 5,00-6,53. Tingkat kesukaan terhadap tekstur menunjukkan ada perbedaan nyata $(p=0,000)$. Tekstur choux pastry kering yang dihasilkan renyah dan berongga. Hal ini disebabkan karena bahan baku dalam pembuatan choux pastry ini adalah tepung terigu. Tepung terigu mengandung gluten yang tersusun atas gliadin dan glutenin yang merupakan komponen tidak larut air dan bersifat viskoelastis. Gliadin menyebabkan gluten bersifat elastis dan glutenin akan membuat adonan mampu menahan gas dan membentuk kerangka karena gelatinisasi pati pada saat proses pemanggangan (Ratnasari \& Pangesthi, 2014). Semakin banyak substitusi tepung ikan gabus menyebabkan terjadinya penurunan tingkat kesukaan. Hal ini menyebabkan choux pastry yang dihasilkan kurang berongga. Sejalan dengan penelitian (Ningrum, Suhartatik, \& Kurniawati, 2016). Penggunaan tepung ikan patin yang semakin besar dalam pembuatan biskuit akan menghasilkan produk yang keras, hal ini disebabkan karena tepung ikan tidak mengandung gluten sehingga adonan menjadi tidak mengembang.

\section{KESIMPULAN}

Kesimpulan dalam penelitian ini adalah substitusi tepung ikan gabus dalam pembuatan choux pastry kering berpengaruh nyata terhadap tingkat kesukaan panelis terhadap warna, aroma dan tekstur akan tetapi tidak berpengaruh nyata terhadap rasa. Formulasi choux pastry kering yang paling disukai adalah dengan substitusi tepung ikan gabus sebesar $15 \%$.

\section{UCAPAN TERIMA KASIH}

Ucapan terimakasih disampaikan kepada Direktur Poltekkes Kemenkes Riau melalui Kepala UPPM atas dana penelitian yang diberikan dalam bentuk Penelitian Dosen Pemula. 


\section{DAFTAR PUSTAKA}

AOAC. (2005). Official Methods of Analysis. USA: Assosiation of Official Chemist. Inc.

Arsa, M. (2016). Proses Pencoklatan (Browning Process) Pada Bahan Pangan. Denpasar.

Assadad, L., Hakim, A. R., \& Widianto, T. N. (2015). Mutu Tepung Ikan Rucah Pada Berbagai Proses pengolahan. In Seminar Nasional Tahunan XII Hasil Penelitian Perikanan dan Kelautan (pp. 53-62). Yogyakarta.

Betari, K. D., \& Pangesthi, L. T. (2016). Pemanfaatan Tepung Tiwul Tawar Instan Sebagai Substitusi Tepung Terigu Dalam Pembuatan Sus Kering. E-Journal Boga, 5(1), 168-174.

BSN. SNI Tepung Ikan, Pub. L. No. SNI 01-2715-1996 (1996). Indonesia.

Fatmawati, \& Mardiana. (2014). Analisa Tepung Ikan Gabus Sebagai Sumber Protein. Octopus, 3, 235-243.

Handoyo, W. T., \& Assadad, L. (2016). Karakterisasi Proses Produksi dan Kualitas Tepung Ikan di Beberapa Pengolahan Skala Kecil. In Seminar Nasional Tahunan XIII hasil Penelitian Perikanan dan Kelautan (pp. 197-206). Yogyakarta.

Kusumawardhani, T., Mexitalia, M., \& Kosnadi, L. (2006). Pemberian Diet Formula Tepung Ikan Gabus (Ophiocephalus striatus ) pada Sindrom Nefrotik, 8(3), 251-256.

Ningrum, A. D., Suhartatik, N., \& Kurniawati, L. (2016). Karakteristik Biskuit Dengan Substitusi Tepung Ikan Patin (Pangasius sp) dan Penambahan Ekstrak Jahe Gajah (Zingiber officinale var. Roscoe). Jurnal Teknologi Dan Industri Pangan, 2(1), 53-60.

Nugroho, H. I., Dewi, E. N., \& Rianingsih, L. (2016). Pengaruh Penambahan Tepung Daging Ikan Lele Dumbo (Clarias gariepinus) Terhadap Nilai Gizi Roti Tawar. J. Peng. \& Biotek. Hasil Pi., 5(4), 11-19.

Ratnasari, Y., \& Pangesthi, L. T. (2014). Pengaruh Substitusi Mocaf (Modified Cassava Flour) dan Jumlah Air Terhadap Hasil Jadi Choux Paste. E-Jurnal Boga, 03, 141-148.

Sari, D. K., Marliyati, S. A., Kustiyah, L., Khomsan, A., \& Gantohe, T. M. (2014). Uji Organoleptik Formulasi Biskuit fungsional Berbasis Tepung ikan Gabus ( Ophiocephalus striatus ). Agritech, 34(2), 120-125.

SNI, B. S. N. (1992). SNI 01-2891-1992: Cara Uji Makanan dan Minuman. Jakarta.

Wulansari, P. D. (2016). Pengaruh Penggunaan Tepung Jagung (Zea mays L.) Sebagai Bahan Komposit Tepung Terigu Terhadap Kualitas Choux Pastry Kering. Universitas Negeri Semarang. 